\title{
Mesoscale processes regulating the upper layer dynamics of Andaman waters during winter monsoon
}

\author{
*Salini Thaliyakkattil Chandran ${ }^{1}$, Smitha Bal Raj ${ }^{2}$, Sajeev Ravindran ${ }^{1}$, Midhunshah Hussain ${ }^{1}$, \\ Muhammed Rafeeq ${ }^{3}$ \\ 1 Cochin University of Science and Technology, Kochi, 682016, India \\ 2 Centre for Marine Living Resources \& Ecology, Kochi, 682037, India \\ 3 Center for Environment \& Water, Research Institute, King Fahd University of Petroleum \& Minerals, Dhahran 31261, Saudi Arabia \\ *Corresponding Author. email: salinitc@gmail.com, ph.+91 984688249
}

1 Abstract

2 The characteristic of cold core eddies and its influence on the hydrodynamics and biological

3 production in Andaman waters were studied using in situ and satellite observations. The specific

4 structure and patterns of the temperature-salinity (T-S) profiles, nutrients and chl a indicate the

5 occurrence of the eddy, the spatial extent of which is well marked in sea surface height anomaly

6 (SSHA). The Cyclonic Eddies are centered at $7^{\circ} \mathrm{N}$ and $86^{\circ} \mathrm{E}, 13^{\circ} \mathrm{N}$ and $88^{\circ} \mathrm{E}$ and $13^{\circ} \mathrm{N}$ and $93^{\circ} \mathrm{E}$

7 (CE1, CE2 and CE3 respectively). In situ measurements are done in the eastern flank CE1 along

$8 \quad 8^{\circ} \mathrm{N}$ and $92.5-93.5^{\circ} \mathrm{E}$. Vertical currents recorded using Acoustic Doppler Current Profiles

9 (ADCP) shows northward flow along the track $\left(0.3 \mathrm{~m} \mathrm{~s}^{-1}\right)$ while along the western flank, the

10 flow is weak and southward. This evidence the occurrence of cyclonic eddy and the altimetry

11 derived SSHA depicts the spatial extent. Analysis to explore the possible forcing to induce the

12 occurrence of eddy, indicate baroclinic instability ( $\mathrm{Ri}<0.0001$ ) in the water column due to

13 vertical shear in the horizontal flow. Bay of Bengal $(\mathrm{BoB})$ water evidenced from the T-S profiles

14 and the semi-annual Rossby wave are the contributing factors of eddy formation. Whereas, the

15 wind stress curl is not a major inductive of divergence in the region. The eddy influenced the

16 nutrient pattern $\left(\mathrm{NO}_{2}, \mathrm{NO}_{3}, \mathrm{PO}_{4}\right.$ and $\left.\mathrm{SiO}_{4}\right)$ and the biological production (chl a) in the region

17 though the influence is less significant. CE1 and CE2 are similar in terms of forcing mechanisms

18 while, CE3 is associated with convective mixing processes occurring along the northwest coast

19 of Andaman due to the prevalent cold dry continental air from north east. 
The Sea around the Andaman and Nicobar Island chain is influenced by reversing monsoon with moisture rich summer winds and dry continental air flow from north east during winter (Potemra et al., 1991). The region receives enormous runoff and suspended matter from Ayeyarwady Salween river system, which has got significant influence on the hydro-dynamics and oceanography (Robinson et al., 2007). The region is characterised with strong stratification, preventing vertical mixing causing lack of availability of nutrients in the upper layers resulting oligotrophy. The seasonal winds, moderate or strong, though experience during the summer and winter months, are not found to exert any divergence or positive curl and nutrient pumping to enrich the biological production is least encountered for the waters. The sea is less productive compared to Arabian sea and Bay of Bengal and the average primary production during fall inter-monsoon is $283.19 \mathrm{mg} \mathrm{C} \mathrm{m}^{-2} \mathrm{day}^{-1}$ followed by spring inter-monsoon ( $249 \mathrm{mg} \mathrm{C} \mathrm{m}^{-2}$ day $\left.^{-1}\right)$, summermonsoon (238.98 $\mathrm{mg} \mathrm{C} \mathrm{m}^{-2}$ day $^{-1}$ ) and wintermonsoon (195.47 $\mathrm{mg} \mathrm{C} \mathrm{m}^{-2}$ day $^{-1}$ ) [Sanjeevan et al., 2012]. Earlier observations show that the eastern and western part of the island chain is governed by distinct water properties, when west shows the typical BoB (Bay of Bengal) characteristics, Northeast is highly influenced by the Ayeyarwady and Salween river system and the southeast by the productive environment of Malacca strait (Salini et al., 2010). The region is least explored for the oceanic processes, and the surveys conducted so far for understanding the biodiversity and the basin scale environment associated with the living resources indicate, absence of any major or seasonal processes, that results in nutrient pumping to alter the production pattern. However, with the emergence of satellite techniques, especially the Altimtery and ocean color imageries information on mesoscale to basin scale that contribute to the understanding of the upper layer dynamics have been strengthened. Explanations have come on such major processes in the Bay of Bengal, especially on number of eddies and gyres and also the impact of cyclones which causes enormous mixing in its path. Eddies are mesoscale processes (50-200km diameter), and ubiquitous feature of the ocean occurs in both clock wise and anti-clock wise direction resulting convergence/divergence at the centre.

Mesoscale eddies play a dominant role to transport salt, heat and nutrients within the ocean (Dong et al., 2014) and enhances the local production in generally oligotrophic areas (Hyrenbach et al. 2006) ultimately influencing the production pattern in each trophic level (Bakun 2006). Mechanism behind the eddy formation is suggested by many researchers. Different driving mechanism have been attributed for the eddy formation such as Ekman pumping, remote forcing from the equatorial Kelvin wave reflecting off the eastern boundary as Rossby wave. According 
to $\mathrm{Yu}$ et al. (1999), westward propagating Rossby wave excited by the remotely forced Kelvin wave contribute substantially to the variability of the local circulation in ocean. Using the multilayer model, Potemra et al. (1991) described coastal Kelvin wave, which originates at the equator, propagating around the entire western perimeter of the region around both the Andaman Sea and the Bay of Bengal. Mesoscale eddies are observed in the coastal waters of the Andaman and Nicobar Islands (Hacker et al. 1998; Chen et al. 2013) based on in situ hydrographic measurements. Burnaprathepart (2010) described the presence of eddy in Andaman Sea and its role in enhancing the primary productivity synthesizing number of vertical profiles on chl a, major nutrients, temperature and salinity. The eddy is identified based on the SSHA imagery and the geostrophic current pattern indicating the low and the anticlockwise circulation pattern resulting divergence and upsloping in the center. The present study, based on a suit of in situ and satellite on physical, chemical and biological measurements, explains the characteristics, generation mechanism and evolution of the eddy and its impact on the regional primary production.

\section{Data and Methodology}

In situ measurements were taken during FORV Sagar Sampada cruise 292 of 21Nov-14 Dec 2011. The environmental characteristics are understood from the station based measurements in the east and west of the island chain. However, focus is given for a transect with 4 stations (Fig. 1) along the eddy periphery, which was observed to be a detached feature from a major eddy centered at $7^{\circ} \mathrm{N} 90^{\circ} \mathrm{E}$. The meteorological parameters like air temperature, air pressure and humidity were also collected through the instruments/sensors attached to the IRAWS onboard in 15 minute interval. Profiles of temperature, salinity, dissolved oxygen and Sigma-t were obtained using SeaBird 911 Plus CTD with Niskin water samplers and deck unit for data acquisition. The datasets are processed for $1 \mathrm{~m}$ bins. Salinity is also derived from water samples collected through Niskin samplers and using Guildline 8400A Autosal Salinometer to validate the CTD derived data. Twelve numbers of 10 liter Niskin water samplers were used to collect water samples from standard depths (surface, 10m, 20m, 30m, 50m, 75m, 100m, 120m, 150m, $200 \mathrm{~m} 300 \mathrm{~m}, 500 \mathrm{~m}, 750 \mathrm{~m}$ and $1000 \mathrm{~m}$ ) for the measurements of dissolved oxygen and nutrients. Temperature-Salinity profiles for the watermass characteristics are based on averaged (climatological) data from Levitus et al. (1994). Monthly composite of the chlorophyll data is obtained from the Distributed Active Archive Center (DAAC) of National Aeronautics and 
84 Space Administration, NASA. Dissolved oxygen was measured by Winkler titration. The analysis of nitrite, nitrate, phosphate and silicate were done using a Skalar Analyser. The bathymetry of the region is analysed using the NIO's modified dataset (Sindhu et al, 2007). The abyssal plain with an even floor is located in the region. NIO modified the original ETOPO5 and ETOPO2v2 bathymetric grids in shallow water regions using the digitized data.

Wind stress curl (daily) is taken from ASCAT processed by NOAA/NESDIS utilizing measurements from the scatterometer instrument aboard the EUMETSAT Metop satellites with a spatial resolution of $25 \mathrm{~km}$. Chl a is taken from MODIS Aqua Level 3 at a spatial resolution of $4 \mathrm{~km}$ which is downloaded from Ocean Color Website and processed using SeaDas. SST is taken from MODIS Aqua Level 3 at a spatial resolution of $4 \mathrm{~km}$ which is downloaded from Ocean Color Website. SSHA data is obtained with 7day temporal resolution from AVISO for the period from January 2003 to January 2013. The cold core eddy is recognized through SSHA with geostrophic current imagery obtained from https://oceanwatch.pifsc.noaa.gov and is centered at $7^{\circ} \mathrm{N}$ and $90^{\circ} \mathrm{E}$ with current moving in cyclonic direction. Net heat flux, Solar radiation, latent heat flux and specific humidity are obtained from http://oaflux.whoi.edu.The in situ observation at $8^{\circ} \mathrm{N}$ along $92.5^{\circ} \mathrm{E}-93.5^{\circ} \mathrm{E}$, is identified as the eastern periphery of the eddy identified.

Vertical sections of currents are derived using hull mounted OS II BB ADCP of $76.8 \mathrm{KHz}$ frequency operated along the ship's track. Current datasets are acquired using VmDas in $8 \mathrm{~m}$ bins and ensemble time of two seconds. The ship heading and navigational informations are also recorded while acquiring the raw data. The first bin record of current started at $16 \mathrm{~m}$ depth. The data in earth co-ordinates were postprocessed using WinADCP, for an ensemble period of 1 minute. Processed data which have a percentage good more than $80 \%$ only are considered for the analysis.

Wavelet transform is an appropriate analysis tool to study multi-scale, non-stationary processes occurring over finite spatial and temporal domain. Here the wavelet used to analyse time series data of oceanographic parameters that contain non-stationary power at many different frequencies. This technique is used to decompose the time series into its frequency components based on the convolution of the original time series with set of wavelet functions and possible to determine both the dominant modes of variability and how those modes vary in time. It expands functions in terms of wavelets, which are generated in the form of translations and dilations of a 
Ocean Sci. Discuss., https://doi.org/10.5194/os-2018-23

Manuscript under review for journal Ocean Sci.

Discussion started: 14 June 2018

114

115

116

117

118

119

120

121

122

123

124

125

126

127

128

129

130

131

132

133

134

135

136

137

138

139

140

fixed function called mother wavelet. Meyers et al (1993) used wavelet analysis to study the propagation of mixed Rossby-gravity waves in an idealized numerical model of the Indian Ocean.

The phase speed for long baroclinic Rossby wave is given by $\mathrm{C}=\frac{-\mathrm{gH}_{0 \beta}}{\mathrm{f}^{2}}$

where $\mathrm{g}$ is the reduced gravity term (taken as $0.04 \mathrm{~m} \mathrm{~s}^{-2}$ for the first baroclinic mode), $\mathrm{H}_{0}$ is the thermocline depth (taken as an annual mean depth of $20^{\circ} \mathrm{C}$ isotherm derived from Levitus et al., 1994), $\mathrm{f}$ is the Coriolis parameter, and $\beta=\frac{\partial \mathrm{f}}{\partial \phi}, \phi$ is the latitude

\section{Results and Discussion}

\section{Physical characteristics of the eddy region (Eddy dynamics)}

The region is characterized with warm $\left(27.6-28^{\circ} \mathrm{C}\right)$, humid $(72-77 \%)$ air and wind is from northeast suggesting the prevalence of northeast monsoon condition of magnitude between 10$12 \mathrm{~m} \mathrm{~s}-1$ with comparatively lower speed (10m s-1) in the western part and higher speed in the eastern part of the eddy (which is named thereafter as CE1).

The SST varies between $28.4-28.8^{\circ} \mathrm{C}$ with lower temperature near coastal water comparing to offshore. The surface salinity (33.00) and density $\left(20.40 \mathrm{~kg} \mathrm{~m}^{-3}\right.$ values are same in coastal and offshore waters. The regional watermass characteristics from temperature, salinity and density profiles show that the area is occupied by Bay of Bengal $(\mathrm{BoB})$ waters with temperature 28.0$28.5^{\circ} \mathrm{C}$, salinity $33.2-33.8$ and density $20.6-20.8 \mathrm{~kg} \mathrm{~m}^{-3}$. Vertical temperature distribution along $8^{\circ} \mathrm{N}$ shows warm $\left(>28.5^{\circ} \mathrm{C}\right)$ and thick isothermal layer $(\sim 54 \mathrm{~m})$ in the western part and it showed a gradual decrease towards east (20m) (Fig.2b). The most important feature in the thermal structure is the upsloping of isothermal layer and is prominent in the subsurface (54$220 \mathrm{~m}$ ) also and the mixed layer depth (MLD) shoaled from west to east (47-19m). The vertical salinity and density distribution show the presence of low saline (32.9-33.1) in the upper $30 \mathrm{~m}$, with an upsloping tendency (Fig.2c, d) as in the case of temperature. Similar pattern is also reflected in density characteristics too.

The vertical current structure at $8^{\circ} \mathrm{N}$ along $92.5^{\circ} \mathrm{E}$ to $93.5^{\circ} \mathrm{E}$ (Fig.3) shows irregular current pattern from surface to $90 \mathrm{~m}$. Along the eastern part of the $100 \mathrm{~km}$ transect, major flow is towards 
south $(\cong 30 \mathrm{~km})$, west to it with a narrow and weak northward flow, followed by major southward drift up to $40 \mathrm{~m}$. However, the response to this irregular pattern is insignificant in the T-S profiles, and so the eastern part of the transect $(\sim 60 \mathrm{~km})$ is not considered for addressing the eddy. In the western flank, the northward and the subsequent flow towards indicate the cyclonic flow direction. The current recorded at $16 \mathrm{~m}$ depth is considered for near surface pattern and this shows the presence of a northern component with magnitude $0.3 \mathrm{~m} \mathrm{~s}^{-1}$ in the eastern part and negligible speed in the western part and it directed towards west. But at $40 \mathrm{~m}$ the current magnitude is decreasing in the eastern flank $\left(0.1 \mathrm{~m} \mathrm{~s}^{-1}\right)$ and increasing magnitude in the western flank $\left(0.1 \mathrm{~m} \mathrm{~s}^{-1}\right)$ with direction changing from northeast to southwest. The current at $88 \mathrm{~m}$ also follow the same pattern but magnitude changes from $0.5 \mathrm{~m} \mathrm{~s}^{-1}$ in the western part and $0.4 \mathrm{~m} \mathrm{~s}^{-1}$ in the eastern part. The upsloping in the T-S profiles concurrent to this confirms the feature as a subsurface cyclonic eddy. The flow in the eastern flank is towards north $\left(0.3 \mathrm{~m} \mathrm{~s}^{-1}\right)$ and at west it is to south $\left(0.5 \mathrm{~m} \mathrm{~s}^{-1}\right)$. The data is analyzed for all $8 \mathrm{~m}$ cells up to $88 \mathrm{~m}$ depth, and found to follow the same pattern as that of near surface but with a decreasing magnitude. Below $88 \mathrm{~m}$ the dataset contains spurious values and so discarded.

\section{Generation Eddy Mechanism}

The possible physical mechanism that govern the eddy includes the wind stress curl, topographic instability, shear flows, baroclinic instability and the radiation of Rossby waves from pole ward propagating coastal Kelvin waves etc. (White, 1977; Kessler, 1990). Daily wind stress curl is examined to identify the local forcing that contributes to the formation and sustenance of the eddy. Curl of the eddy region from ASCAT wind data shows negative values in the range between-5.6x $10^{-8}$ to $-8.24 \times 10^{-8} \mathrm{~Pa} \mathrm{~m}^{-1}$, indicating convergence and hence the contribution due to wind stress curl is ruled out.

Other possibility of eddy generation mechanism is the differential mixing of region with the adjacent sea mainly through inflow from Malacca Strait and freshwater influx from adjoining rivers leads to strong density variations in the water column. This variation may reduce or enhance the mechanical effects in the form of eddy or meanders in the region. This is measured based on the estimated Richardson Number (Ri). According to Miles (1961) the flow is stable if $\mathrm{Ri}>0.25$. 
$170 \quad \mathrm{Ri}$ is calculated as $\mathrm{Ri}=\frac{\mathrm{N}^{2}}{\left(\frac{\mathrm{u}}{\partial \mathrm{z}}\right)^{2}}$

171

$172 \quad \mathrm{~N}^{2}=\frac{-\mathrm{g}}{\rho_{0}} \frac{\partial \sigma_{\mathrm{t}}}{\partial \mathrm{z}}$ using ADCP.

where $\mathrm{N}^{2}$ is the Brunt Vaisala frequency (BV)

$\mathrm{g}$ is the gravitational acceleration, ${ }^{\rho_{0}}$ is the average sea water density, $\mathrm{z}$ is the depth, $\sigma \mathrm{t}$ is $\rho-1000$ where $\rho$ is the sea water density. The denominator term $\partial \mathrm{u} / \partial \mathrm{z}$ is velocity gradient which is an indicator of strength of mechanical generation calculated from vertical current profiles acquired

The low BV (avg 3.165 $\times 10^{-5} \mathrm{~s}^{-1}$ ) and large velocity gradient (avg $3.968 \mathrm{~s}^{-2}$ ) resulted into low Ri (avg 0.0001) indicating unstable well mixed water column. These leads to instability in the water column and favors eddy like perturbation in the region.

Instability arises either as a result of mixing of different water masses or due to the shear flows. Mixing with other water masses can be ruled out as we have a clear evidence of presence of BoB water in the eddy region from the T-S profiles. Other option is the prevalence of any planetary waves that modulate the horizontal flow and to induce shear and thereby instability. And such instability has been well reported along this region by Schott et al., 2009 and Rao et al., 2010that planetary waves influence the near surface circulation through local and remote forcing. The role of this planetary wave influence on the eddy generation mechanism is examined using altimeter data and mapping the planetary wave propagation to identify their influence on regional circulation. Referring $\mathrm{Yu}(2003)$, the Hovmuller diagram of SSHA at $8^{\circ} \mathrm{N}$ along $89^{\circ} \mathrm{E}$ to $94^{\circ} \mathrm{E}$ is analyzed to track the planetary wave are plotted (Fig.4). Low SSHA in this region from midNovember to mid-January indicates the presence of upwelling mode Rossby wave (Gireeshkumar et al., 2011). Negative SSHA is almost horizontal indicating a fast propagation of Rossby wave. Further west (near to the eddy location) negative SSHA showed a steeper slope, indicating a slower propagation. The westward propagating signal took about 45-60 days to travel from the coast of Nicobar Island chain (Potemra et al., 1991) to the core of the eddy region, which yields the phase velocity of the westward signal at $0.20 \mathrm{~m} \mathrm{~s}^{-1}$. The theoretical phase speed of Rossby wave at $8^{\circ} \mathrm{N}$ which propagate westwards is calculated as $0.21 \mathrm{~m} \mathrm{~s}^{-1}$. This suggests that the signal appearing in the plot is a Rossby wave that has been generated on the 
west coast of Nicobar island chain. The estimated speed of the wave is close to the theoretical wave speed and the estimate also compares well with earlier results of Yang et al. (1998), Yu (2003), Rao et al. (2002) and Gireesh Kumar et al. (2011). The Rossby waves were produced by radiation from the west coast of Nicobar Island chain in association with poleward propagating coastal Kelvin waves (Potemra et al. 1991,). Nuncio and Prasanna Kumar (2012) suggested that the interaction of westward propagating Rossby waves and local wind stress curl cause baroclinic instability and meandering in Bay of Bengal to induce eddy like features. Using a numerical model, Kurien et al. (2010) also concluded that baroclinic instability plays a key role in meander growth and eddy generation in BoB. Srinivas, et al (2012) argued that coastal Kelvin waves and the associated radiated Rossby waves from the east play a dominant role in the mesoscale eddy generation in Bay of Bengal.

To ascertain the periodicity of SSHA, the data is again subjected to continuous wavelet transforms with Morlet wave as mother wavelet following Torrence and Compo (1998). It is understood from the Fig.6 that the dominant mode of variability is semiannual. In the Andaman waters the wave period is more variable due to the effect of westward propagating Rossby wave from the coastally trapped Kelvin wave (Vialard et al., 2009 and Nienhaus et al., 2012). From the power and global wavelet spectrum (Fig.5), the predominant frequencies are at semiannual and annual modes. The annual mode seems to be reduced in intensity compared to the semiannual mode. On the basis of the results of wavelet analysis, wecould state that the semiannual Rossby waves are significant in the years 2005, 2008, 2010 and 2011, where the annual wavelets are significant in 2006-2009.Therefore, we concluded that the westward propagating Rossby wave radiated from the coastal Kelvin wave contribute to cyclonic eddy in the region.

\section{Chemical and biological response of the eddy}

Concurrent with the thermohaline oscillations, the vertical structure of dissolved oxygen (DO) also demonstrate fluctuations above $90 \mathrm{~m}$ depth. The $4.22 \mathrm{ml} / \mathrm{L}$ DO contour shoaled from a depth of about $47 \mathrm{~m}\left(92.3^{\circ} \mathrm{E}\right)$ to $25-30 \mathrm{~m}$ at eastern flank of the eddy $\left(93.3^{\circ} \mathrm{E}\right)$. The upper nitrate $\left(\mathrm{NO}_{3}\right)$ concentration is in the dectectable levels $(0.67 \mu \mathrm{M}-0.98 \mu \mathrm{M})$ and shows slight upsloping towards the eastern flank $\left(93.3^{\circ} \mathrm{E}\right)$. The phosphate $\left(\mathrm{PO}_{4}\right)$ concentration in the upper water was also at a detectable level and showed a slight upsloping towards the eastern side $(0.12 \mu \mathrm{M}$ at $92.3^{\circ} \mathrm{E}$ and $0.27 \mu \mathrm{M}$ at $\left.93.3^{\circ} \mathrm{E}\right)$. The vertical distribution of silicate $\left(\mathrm{SiO}_{4}\right)$ also showed slight 
Ocean Sci. Discuss., https://doi.org/10.5194/os-2018-23

Manuscript under review for journal Ocean Sci.

Discussion started: 14 June 2018

(c) Author(s) 2018. CC BY 4.0 License.

upsloping towards the eastern periphery $\left(0.77 \mu \mathrm{M}\right.$ at $92.3^{\circ} \mathrm{E}$ to $1.62 \mu \mathrm{M}$ at $\left.93.3^{\circ} \mathrm{E}\right)$ [Table. 1]. Hence, concomitant with the thermohaline characteristics, the vertical distribution of nutrients also showed oscillations in the upper water column.

The physical and chemical characteristics do reflect on the regional biology and this is well reflected in the surface chl a distribution. The chl a derived from ocean colour imagery (Fig. 6) can be illustrate the standing stock of the primary consumers for the optical depth and is $0.5 \mathrm{mg}$ $\mathrm{m}^{-3}$ in the eddy region compared to the nearby region $\left(0.1 \mathrm{mg} \mathrm{m}^{-3}\right)$. This increase within the eddy in association with the nutrient values, explains the impact of churning due to the eddy. And this point out the relevance in occurrence of such mesoscale processes to influence the production marginally in the Andaman waters.

\section{Satellite evidence (SSHA based) for cyclonic eddies}

General purview on distribution of such mesoscale production favourable pockets is examined using monthly SSHA pattern (Fig.7a-d) for the winter monsoon (Nov-Feb) of 2011. This evidenced the presence of three cyclonic eddies, one of which (CE1) is the same we encountered during the in-situ measurements. CE1 was the stronger as indicated with negative SSHA between $5^{\circ}-9^{\circ} \mathrm{N}$ with core at $6.5^{\circ} \mathrm{N}$ latitude and is observed to be propagating from $86^{\circ} \mathrm{E}$ to $91^{\circ} \mathrm{E}$ within one month (November to December).The eddy intensity is more in peak months i.e. in December and January with a negative value of $-0.12 \mathrm{~m}$. CE1 propagates eastward to Andaman waters and in December it is observed at $92^{\circ} \mathrm{E}$. It begins to retract from Andaman waters by the end of January and it is completely replaced by a positive sea surface. But the low is observed in Bay of Bengal waters even during February centered at $87^{\circ} \mathrm{E}$ shifted northwards to $9^{\circ} \mathrm{N}$. The shape of eddy is elliptical with its axis oriented in east west direction. The map also showed a positive SSHA oriented in east west direction in the north of CE1. The eddy CE1 characteristics and generating mechanism is described in the above section using in situ as well as satellite observations.

The SSHA maps also revealed a cyclonic eddy located at $13^{\circ} \mathrm{N}$ and $88^{\circ} \mathrm{E}$ during November with negative anomaly of $-0.07 \mathrm{~m}$. This eddy is marked as CE2. Another eddy, CE3 is noticed at $13^{\circ} \mathrm{N}$ and $93^{\circ} \mathrm{E}$ which is comparatively of strong intensity than the CE2 (eddy at $88^{\circ} \mathrm{E}$ ). In December, the shape of CE2 became elliptical with its axis oriented in an east-west direction along $88^{\circ} \mathrm{E}$. The negative anomaly is more in November with a SSHA of $-0.12 \mathrm{~m}$ and the 
Ocean Sci. Discuss., https://doi.org/10.5194/os-2018-23

Manuscript under review for journal Ocean Sci.

Discussion started: 14 June 2018

(c) Author(s) 2018. CC BY 4.0 License.

Discussions

(c) (i)

259 intensity decreased during December with SSHA of -0.05 at two cores at $88^{\circ} \mathrm{E}$ and $93^{\circ} \mathrm{E}$. CE3is

260 departed from western coast of Andaman to Bay of Bengal region during January with high

261 negative anomaly was replaced by a low value of -0.005 . Negative anomaly is replaced by

262 positive anomaly very near to the western side of the Andaman Island. By the month of

263 February, it is completely departed from the Andaman waters. The CE1, CE2 and CE3 are meso-

264 scale features with diameter varying from $50-250 \mathrm{Km}$.

265 Having recognized eddies from SSHA maps, further we have confirmed the prevailing processes

266 to the surface temperature and chlorophyll. Cyclonic eddies due to the divergent forcing at the

267 center is occupied with sub-surface nutrient rich waters at the core and these area of negative

268 SSHA will be of relatively cool SST and high chlorophyll concentration as compared to other

269 regions.

270 SST is high in the initial phase of wintermonths i.e. in November (Fig.8a) with higher value 271 existed in entire region of Andaman waters $\left(28.2^{\circ} \mathrm{C}-28.8^{\circ} \mathrm{C}\right)$. During December (Fig. $8 \mathrm{~b}$ ), 272 however, the values changed to $27.6^{\circ} \mathrm{C}-28.8^{\circ} \mathrm{C}$. Further during January (Fig. 8c) and February 273 (Fig. 8d) the basin wide temperature was in the range to $27^{\circ} \mathrm{C}-29^{\circ} \mathrm{C}$ and $26^{\circ} \mathrm{C}-29^{\circ} \mathrm{C}$ respectively. 274 Though the Andaman waters were warm in general, the cold core eddies identified show 275 relatively cool temperature due to the prevalent cyclonic flow associated with it. CE1 records 276 temperature $28.6^{\circ} \mathrm{C}$ during Nov, and when the eddy advances to the Andaman waters the surface

277 temperature begins to cool. SST decreases from $28.6^{\circ} \mathrm{C}$ to $28.2^{\circ} \mathrm{C}$ during December. SST again decreased to $27.6^{\circ} \mathrm{C}$ in January. But in February the temperature remains the same as in the case of January. CE2 also shows warm temperature during November $\left(28.8^{\circ} \mathrm{C}\right)$ and decreases to $27.8^{\circ} \mathrm{C}$ in November. The decreasing trend follows in January also $\left(27^{\circ} \mathrm{C}\right)$. The SST remains the same in February also $\left(27^{\circ} \mathrm{C}\right)$. CE3 displays the temperature of $28.6^{\circ} \mathrm{C}$ during November. During December temperature decreases to $28.2^{\circ} \mathrm{C}$ and it again decreases to $27^{\circ} \mathrm{C}$ during January and again decrease during February $\left(26.5^{\circ} \mathrm{C}\right)$. The increased temperature in the eastern Andaman might be due to the intrusion of low saline waters through Malacca strait $\left(28-29^{\circ} \mathrm{C}, 32.3-34\right)$ as inferred by Rama Raju et al., 1981 and Tan et al., 2006

High chlorophyll concentration is expected in eddy region due to enhancement of nutrients at surface. This cold core eddies are important because it is the area of high biological activity. These areas are observed with strong physical and biogeochemical coupling resulting high 
289

290

291

292

293

294

295

296

297

298

299

300

301

302

303

304

305

chlorophyll concentration. Generally, Andaman waters are oligotrophic in nature with less chlorophyll concentrations (Vijayalakshmi et al., 2010). The existence of cyclonic circulation increases chl a level in the eddy region. When the cyclonic flow advances, the increased chl a level was observed in the eddy locations at CE1, CE2 and CE3. CE1 records $0.1 \mathrm{mg} \mathrm{m}^{-3}$ during November and it increased to $0.8 \mathrm{mg} \mathrm{m}^{-3}$ during December and decreased to $0.3 \mathrm{mg} \mathrm{m}^{-3} \mathrm{January}$ (Fig. 7a-d). Chl a level decreased to $0.2 \mathrm{mg} \mathrm{m}^{-3}$ in February. CE2 displays lower chl a $\left(0.2 \mathrm{mg} \mathrm{m}^{-3}\right)$ in November. It increased to $0.8 \mathrm{mg} \mathrm{m}^{-3}$ during December and decreased to $0.6 \mathrm{mg} / \mathrm{m}^{3}$ in January. It shows a lower value of $0.2 \mathrm{mg} \mathrm{m}^{-3}$ in February. CE3 revealed a very low value $\left(0.1 \mathrm{mg} \mathrm{m}^{-3}\right)$ during November. During December, the chl a begin to increase in the eddy region $\left(0.4 \mathrm{mg} \mathrm{m}^{-3}\right)$ and in January also the pattern follows with a concentration of $0.4 \mathrm{mg} \mathrm{m}^{-3}$ and decreased to $0.2 \mathrm{mg}$ $\mathrm{m}^{-3}$ in February.

The role of wind stress curl on inducing the eddy is verified with weekly progress in the wind stress curl (ASCAT) for the pockets. At CE1 the curl varies from $-4.43 \times 10^{-7}$ to $1.28 \times 10^{-6} \mathrm{~Pa} \mathrm{~m}^{-1}$ but the mode of the signal is $-1.47 \times 10^{-7} \mathrm{~Pa} \mathrm{~m}^{-1}$. At CE2 the curl ranges from $-1.38 \times 10^{-6}$ to $1.12 \mathrm{x}$ $10^{-6} \mathrm{~Pa} \mathrm{~m}^{-1}$, signal mode is $-2.15 \mathrm{x} 10^{-8} \mathrm{~Pa} \mathrm{~m}^{-1}$. The wind curl at CE3 shows values between $2.87 \times 10^{-7}$ and $2.09 \times 10^{-6} \mathrm{~Pa} \mathrm{~m}^{-1}$ and mode is $-3.25 \times 10^{-8} \mathrm{~Pa} \mathrm{~m}^{-1}$. However, the occurrence of maximum negative values implies wind is not a dominant causative factor for the generation of eddy.

As we described earlier, the role due to planetary wave for the eddy formation is analysed using the Hovmoller plot of SSHA at $13^{\circ} \mathrm{N}$ and along $85^{\circ} \mathrm{E}$ to $93^{\circ} \mathrm{E}$ (CE2) [Fig.9]. The low SSHA indicated the presence of upwelling mode Rossby wave in the region. It exhibits a continuous westward propagation of a low SSHA signal along $13^{\circ} \mathrm{N}$. This point out the existence of the westward propagating Rossby waves in the region. The signal takes 80-90 days travelling from the Andaman coast to the eddy core region at $88^{\circ} \mathrm{E}$ which have a phase velocity of $0.053 \mathrm{~m} \mathrm{~s}^{-1}$. The theoretical phase speed of westward propagating signal at $13^{\circ} \mathrm{N}$ is calculated as $0.055 \mathrm{~m} \mathrm{~s}^{-1}$. The estimated speed is well compares with the theoretical speed (Jury and Huang, 2004). The baroclinic instability due to westward propagating Rossby wave plays a dominant role in the eddy generation and sustenance in Andaman and Bay of Bengal.

At CE3 the surface temperature is low compared to nearby location $\left(27-27.2^{\circ} \mathrm{C}\right)$ and the MLD is also deep (>70m). Wind is northeasterly with magnitude 4 to $7 \mathrm{~m} \mathrm{~s}^{-1}$. The specific humidity 14 to $18 \mathrm{~g} / \mathrm{kg}$ implies the dry continental air during the period. Net heat flux varies from ${ }^{-9} 98$ to ${ }^{-1} 134 \mathrm{~W}$ 
$320 \mathrm{~m}^{-2}$ during November - February. This causes heat loss due to evaporation (latent heat flux-220-

$321312 \mathrm{~W} \mathrm{~m}^{-2}$ ) resulting cooling in the sea surface. Solar radiation varies from 114 to $170 \mathrm{~W} \mathrm{~m}^{-2}$ in

322 the eddy region. This low solar insolation reduces the SST and resulting densification of water.

323 Thus, the surface water sinks and nutrient rich water entrains from deeper depths. This evince

324 that the atmospheric forcing causes surface cooling and the resulting convective mixing entrains

325 nutrients into the upper layer which activates the primary production (Prasanna Kumar and

326 Prasad, 1996, Madhupratap et al., 1996).

\section{Conclusion}

328 The column dynamics, forcing mechanisms, chemical and biological responses of cyclonic eddies is explained for the Andaman waters based on a suit of in situ and satellite datasets. The processes are small scale in nature with 100-250 km diameter and are found to be induced as a result of baroclinic instability arised due to the westward propagating Rossby wave, semi-annual mode with phase speed $0.20 \mathrm{~m} \mathrm{~s}^{-1}$ and $0.55 \mathrm{~m} \mathrm{~s}^{-1}$ respectively for CE1 and CE2, while CE3 associated with the process of convective mixing process occurring in the region due to cold dry continental air from north east. The study put forward that, in addition to the mesoscale processes triggering biological production, the convective mixing occurring along the Northwest coast of Andaman is taking a substantial role, though limited to a narrow strip along the coast. The substantial increases in the regional surface biological production indicate the complementary role of such processes in bringing up the quality of production in Andaman waters. The role of convective mixing and eddies in the dynamics of the Andaman waters are explained for the first time through this study.

Acknowledgements

Authors are grateful to the Ministry of Earth Sciences for supporting the work and for providing facilities onboard FORV Sagar Sampada for in situ measurements. All the fellow participants of the cruise FORV SS292 are thankfully acknowledged. In situ data are obtained from FORV Data Centre in CMLRE. ASCAT Scatterometer wind field is obtained from NOAA/NESDIS. The TOPEX/Poseidon SSHA product is generated from the Merged Geophysical Data Record. Chlorophyll data was retrieved from GSFC NASA. Heat flux data is provided by WHOI OAFlux project. 
Ocean Sci. Discuss., https://doi.org/10.5194/os-2018-23

Manuscript under review for journal Ocean Sci.

Discussion started: 14 June 2018

Bakun, A. (2006). Fronts and Eddies as Key Structures in the Habitat of Marine Fish Larvae:Opportunity, Adaptive Response and Competitive Advantage .Scientia Marina, 70 (S2), $105-122$.

Buranapratheprat, A., Laongmanee, P., Sukramongkol, N., Prommas, R., Promjinda, S., \& Yanagi, T. (2010). Upwelling Induced by Mesoscale Cyclonic Eddies in the Andaman Sea. Coastal Marine Science, 34 (1), 68-73.

Chen, X., Pan, D., Bai, He, X., Chen, C.A., \& Hao, Z. (2013). Episodic Phytoplankton BloomEvents in the Bay of Bengal Triggered by Multiple Forcings. Deep Sea Research Part I: Oceanographic Research Papers,73,17-30.

Dong, C., McWilliams, J.C., Liu, Y., \& Chen, D (2014). Global heat and salt transports by eddy movement.Nat. Commun., 5, 3294.

Girishkumar, M.S., Ravichandran, M., McPhaden, M.J., \& Rao, R.R. (2011). Intraseasonal variability in barrier layerthickness in the south central Bay of Bengal. Journal of Geophysical Research, 116, C03009.

Hacker, P., E. Firing, J. Hummon, Gordon, A.L., \& Kindle, J.C. (1998). Bay of Bengal Currents during the Northeast Monsoon. Geophysical Research Letters. 25 (15), 2769-2772.

Hyrenbach, K. D., Veit, R.R., Weimerskirch, H., \& Hunt, G.L. (2006). Seabird Associations with Mesoscale Eddies: The Subtropical Indian Ocean. Marine Ecology Progress Series, 324, $271-$ 279.

Jury, R. M., \& Huang, B. (2004). The Rossby wave as a key mechanism of Indian Ocean climate variability, Deep Sea Res. Part I, 51, 2123-2136.

Kessler, W. S. (1990). Observations of long Rossby waves in the northern tropical Pacific.J. Geophys. Res., 95, 5183-5217.

Kurien, P., Ikeda, M., \& Valsala, V.K. (2010). Mesoscale variability along the east coast of India in spring as revealed from satellite data and OGCM simulations, J. Oceanogr., 66, 273-289.

Levitus, S., \& Boyer, T. (1994). World Ocean Atlas 1994, Vol 4: Temperature, NOAA Atlas NESDIS 4, U.S. Govt. Printing Office, 150. 
Ocean Sci. Discuss., https://doi.org/10.5194/os-2018-23

Manuscript under review for journal Ocean Sci.

Discussion started: 14 June 2018

Levitus, S., Burgett, R., \& Boyer, T. (1994): World Ocean Atlas 1994, Vol 3: Salinity, NOAA Atlas NESDIS 3, U.S. Govt. Printing Office, 150.

Madhupratap, M., Prasanna Kumar,S., Bhattathiri, P.M.A., Dileep kumar, M., Raghukumar, S., Nair., K.K.C., \& Ramaiah, N. (1996). Mechanism of the biological response to winter cooling in the northeastern Arabian Sea. Nature ,384, 549 - 552.

Meyers, S. D., Kelly, B.G., \& O’Brien, J.J. (1993). An introduction to wavelet analysis in oceanography and meteorology: With application to the dispersion of Yanai waves. Mon. Wea. Rev., 121, 2858-2866.

Miles, J.W. (1961). On the stability of heterogeneous shear flows. Journal of Fluid Mechanics, $10,496-508$

Nienhaus, M. J., Subrahmanyam, B., \& Murty, V.S.N. (2012). Altimetric observations and model simulations of coastal Kelvin Waves in the Bay of Bengal, Mar. Geod., 35(1), 190-216.

Nuncio, M., \& Prasanna Kumar, S. (2012). Life cycle of eddies along the western boundary of the Bay of Bengal and their implications, J. Marine Syst., 94, 9-17.

Potemra, J.T., Luther, M.E., \& O'Brien, J.J. (1991). The seasonal circulation of the upper ocean in The Bay of Bengal. Journal of Geophysical Research, 96, 667-683.

Prasanna Kumar, S. \& Prasad, T.G. (1996). Winter cooling in the northern Arabian Sea. Current Science, 71, 834-841.

Rama Raju, D. V., Gouveia, A. D., \& Murthy, C. S. (1981). Some physical characteristics of Andaman Sea Waters during winter. Indian Journal of Marine Sciences, 10, 211-218.

Robinson, R.A.J., Bird, M.I., Oo, N.W, Hoey, T.B., Aye, M.M.D., Higgitt, L., Lud, X.X., Swe, A., Tun, T., \& Win, S.L. (2007). The Irrawaddy river sediment flux to the Indian Ocean:the original nineteenth-century data revisited. Journal of Geology. 115, 629-640.

Salini, T.C., Fanimol, C.L., Smitha, B.R., Jayalakshmi, K.J., Asha Devi, C.R., Sanjeevan, V.N., Saravanane, N., \& Sajeev, R. (2010). Oceanography of the Andaman Waters: Physico-chemical and biological characteristics during Januaryuary 2009. In: Indian Ocean Marine Living 
Ocean Sci. Discuss., https://doi.org/10.5194/os-2018-23

Manuscript under review for journal Ocean Sci.

Discussion started: 14 June 2018

(c) Author(s) 2018. CC BY 4.0 License.

403

404

405

406

407

408

409

410

411

412

413

414

415

416

417

418

419

420

421

422

423

424

425

426

427

428

Resources, Book of Abstracts (Ed. G.V.M.Gupta et al), Centre for Marine Living Resources and Ecology, Ministry of Earth Sciences, Kochi, 29.

Sanjeevan, V.N., Smitha, B.R., Ashadevi, C.R., Abdul Jaleel, K.U. and Jayalalshmi, K.J., 2011. Revalidation of Potential Yield from Indian EEZ.A trophodynamic approach. In Report of the Working Group for revalidating the potential of fishery resources in the Indian EEZ, New Delhi.

Schott, F. A., Xie, S.P., \& McCreary Jr., J.P. (2009). Indian Ocean circulation and climate variability, Rev. Geophys., 47, RG1002.

Sindhu, B., Suresh, I., Unnikrishnan, A.S., Bhatkar N.V., Neetu, S., Michael, G S. (2007). Improved bathymetric datasets for the shallow water regions in the Indian Ocean. J. Earth Syst. Sci., 116(3), 261-274.

Sreenivas, P., Chowdary, J.S., Gnanaseelan., C. (2012b). Impact of tropical cyclones on the intensity and phase propagation of fall Wyrtki jets.Geophys Res. Lett.,9,L22603.

Tan, C.K., Ishizaka, J., Matsumura, S., Md.Yusoff, F., Hj.Mohamed, \& M.I. (2006). Seasonal variability of SeaWiFS chlorophyll a in the Malacca Straits in relation to Asian monsoon. Continental Shelf Research, 26, 168-178.

Torrence C., \& Compo, G.P. (1998). A Practical Guide to Wavelet Analysis, Bull. of the American Met. Soc., 79, 61-78.

Vialard, J., Shenoi, S.S.C., McCreary Jr, J.P., Shankar, D., Durand, F., Fernando, V., \& Shetye, S.R. (2009). Intraseasonal response of the northern Indian Ocean coastal waveguide to the Madden-Julian Oscillation, Geo. Phys. Res. Letts., 36.

Vijayalakshmi R. Nair, \& Gireesh, R. (2010). Biodiversity of chaetognaths of the Andaman Sea. Indian Ocean. Deep Sea Research II, 57, 2135-2147.

White, W. B. (1977). Annual forcing of baroclinic long waves in the tropical North Pacific.J. Phys. Oceanogr., 7, 50-61.

Yang, J., Yu, L., Koblinsky, C.J., \& Adamec, D. (1998). Dynamics of the seasonal variations in the Indian Ocean from TOPEX/POSEIDON sea surface height and an ocean model, Geophys. Res. Letts., 25 (11), 1915 - 1918. 
Ocean Sci. Discuss., https://doi.org/10.5194/os-2018-23

Manuscript under review for journal Ocean Sci.

Discussion started: 14 June 2018

(C) Author(s) 2018. CC BY 4.0 License.

$430 \mathrm{Yu}, \mathrm{L}$. (2003). Variability of the depth of the $20^{\circ} \mathrm{C}$ isotherm along $6^{\circ} \mathrm{N}$ in the BoB: its response

431 to remote and localforcing and its relation to satellite SSH variability. Deep-Sea ResearchII, 50,

$432 \quad 2285-2304$.

433 Yu, L. S., \& Rienecker, M.M. (1999). Mechanisms for the Indian Oceanwarming during the

434 1997-98 El Nino. Geophys. Res. Lett., 26735738.

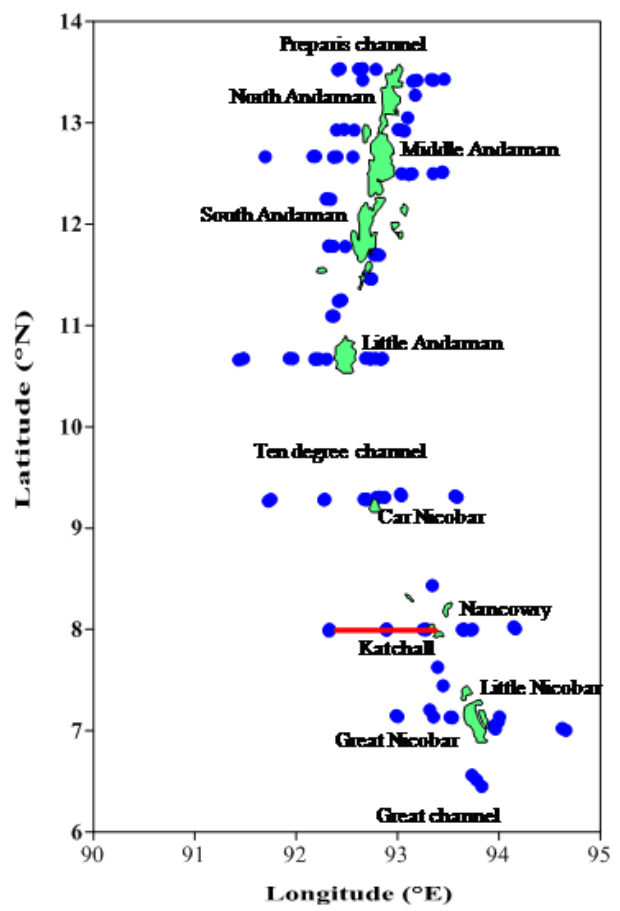

- Station Location of cruise 292 in November-December 2011

- Eddy stations

Fig. 1 Station Location
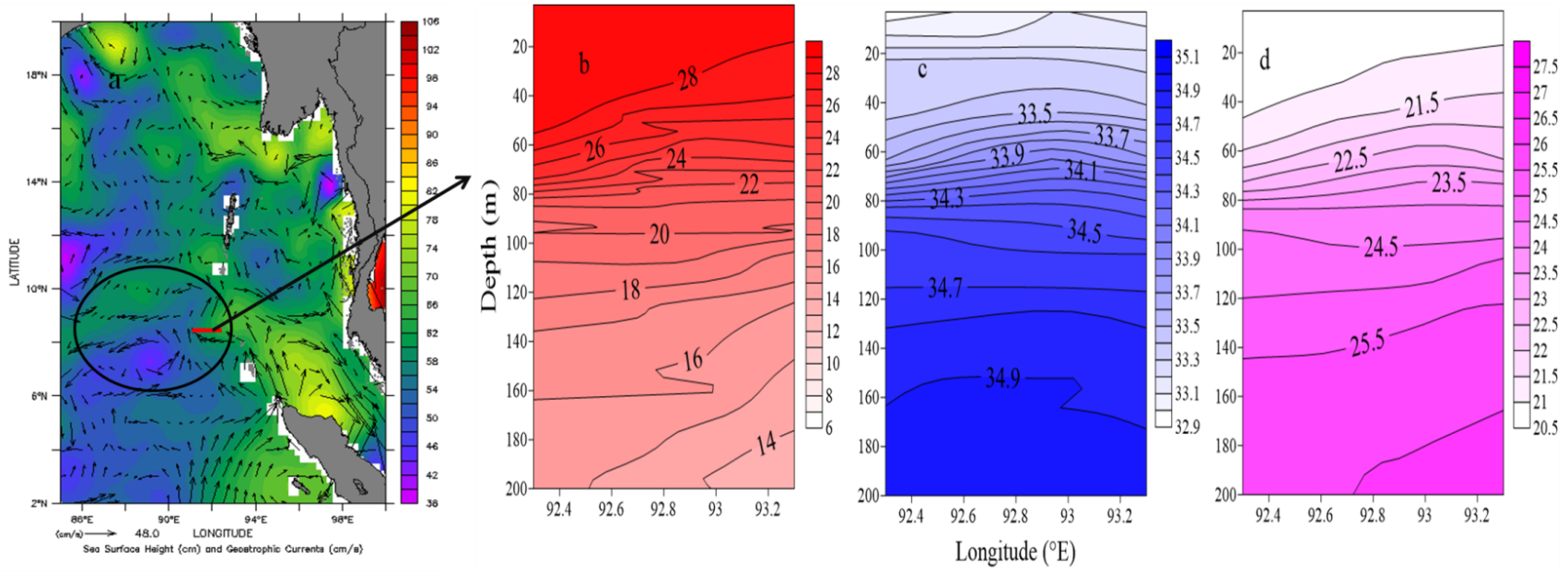
Fig. 2 a) Sea Surface Height and geostrophic current and the eddy location b) Vertical temperature, c) salinity and d) density distribution at the eddy location
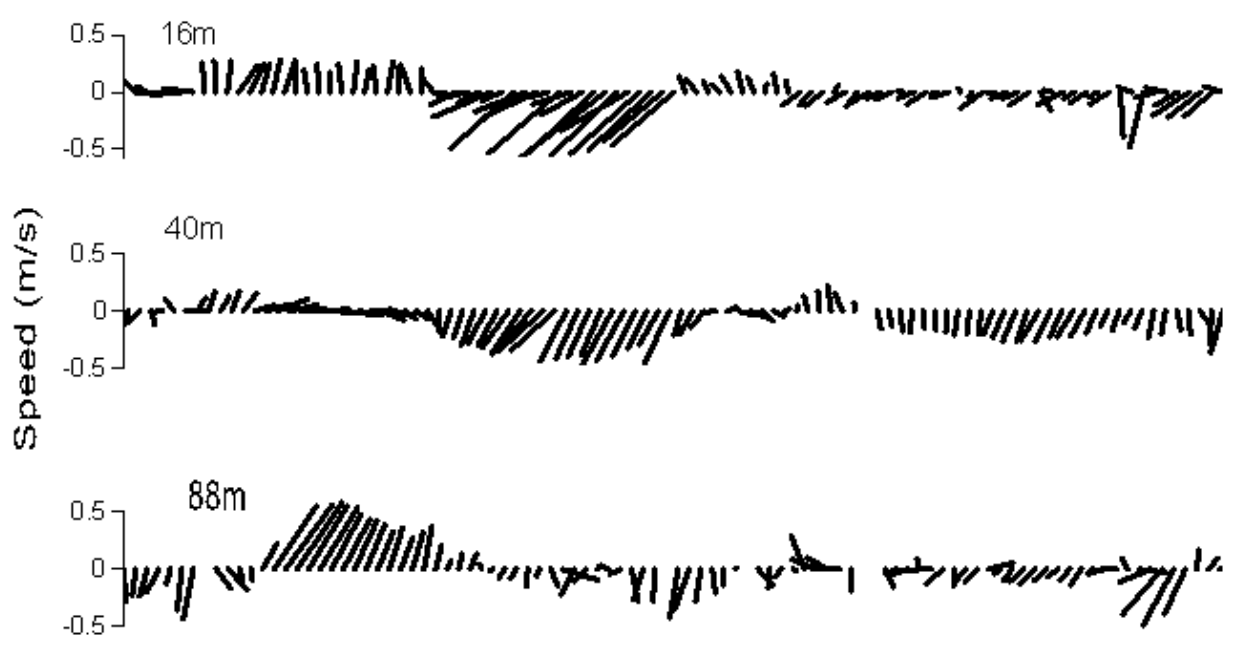

Fig. 3 Vertical current pattern along $8^{\circ} \mathrm{N}$

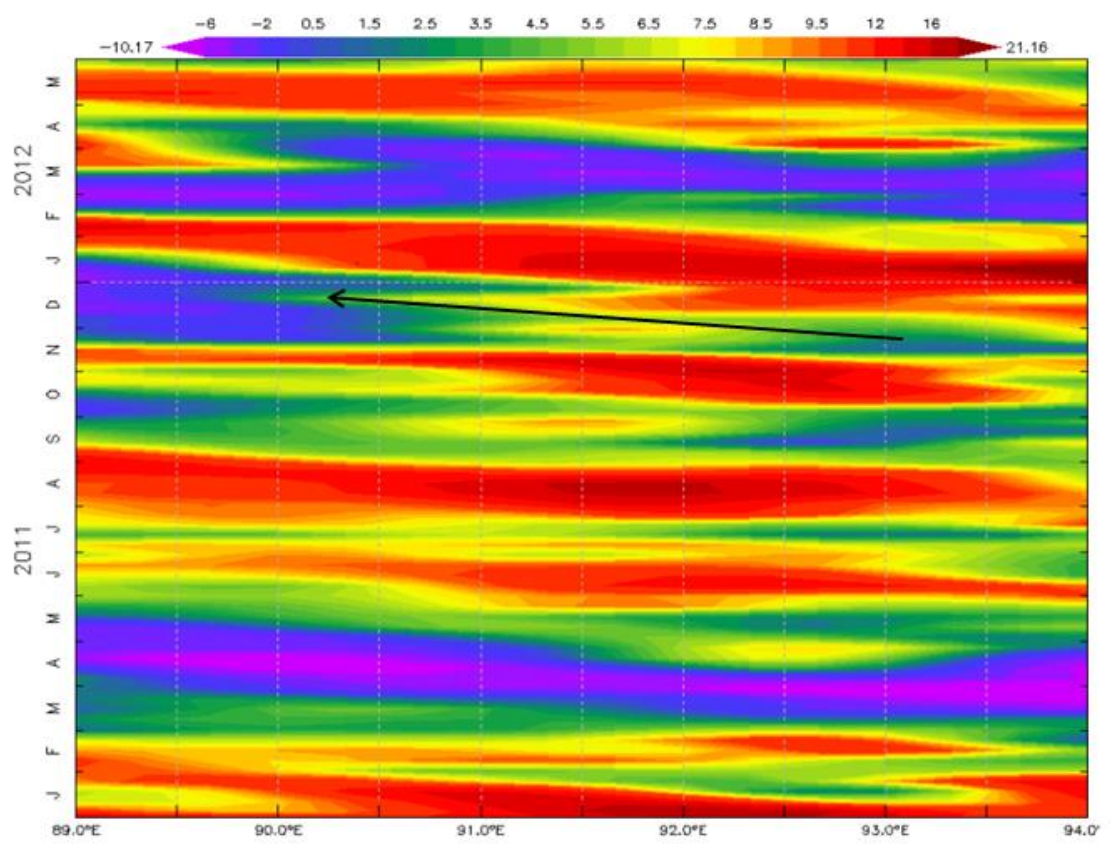

Fig. 4 Hovmuller diagram of SSHA along $8^{\circ} \mathrm{N}$ 
Ocean Sci. Discuss., https://doi.org/10.5194/os-2018-23

Manuscript under review for journal Ocean Sci.

Discussion started: 14 June 2018

(c) Author(s) 2018. CC BY 4.0 License.

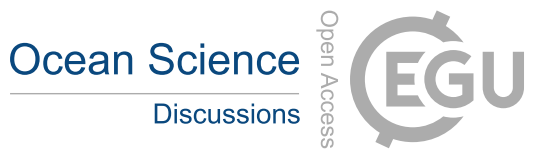

(c) (i)

Page 18
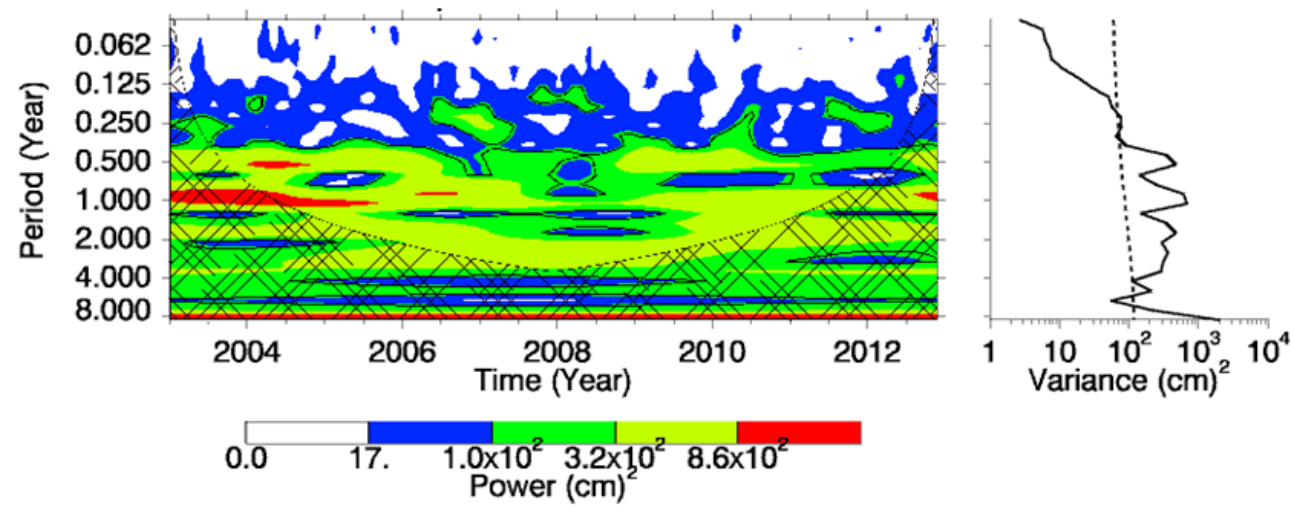

Fig. 5 wavelet power spectra of SSHA

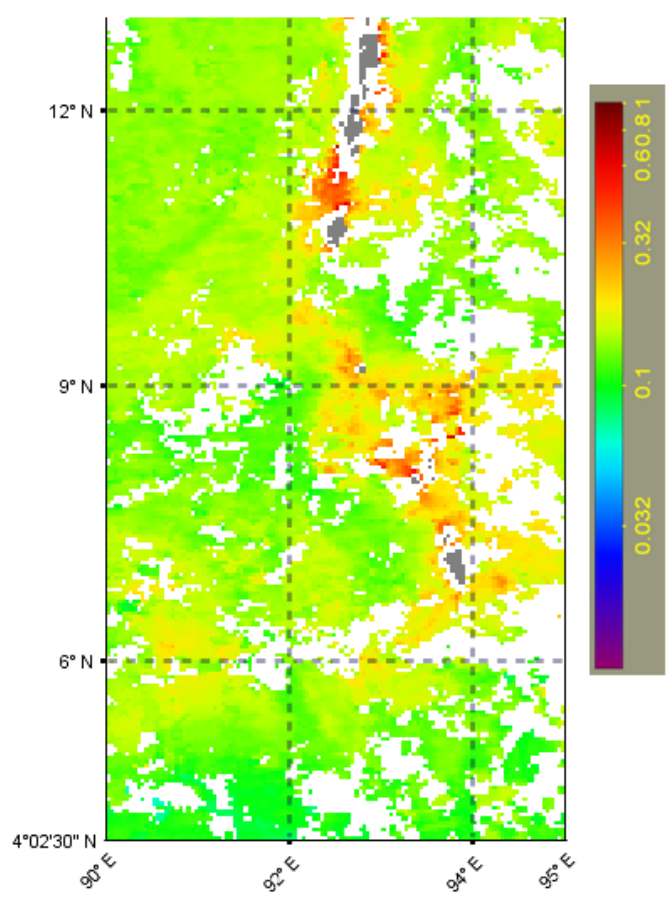

Fig. $6 \mathrm{chl}$ a pattern during the in situ observation 
Ocean Sci. Discuss., https://doi.org/10.5194/os-2018-23

Manuscript under review for journal Ocean Sci.

Discussion started: 14 June 2018

(C) Author(s) 2018. CC BY 4.0 License.

\section{(c) (i)}


Ocean Sci. Discuss., https://doi.org/10.5194/os-2018-23

Manuscript under review for journal Ocean Sci.

Discussion started: 14 June 2018

(c) Author(s) 2018. CC BY 4.0 License.

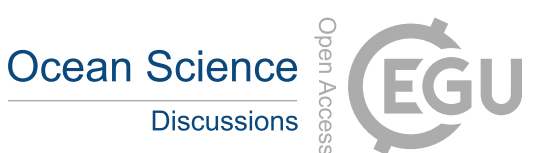

Page 20
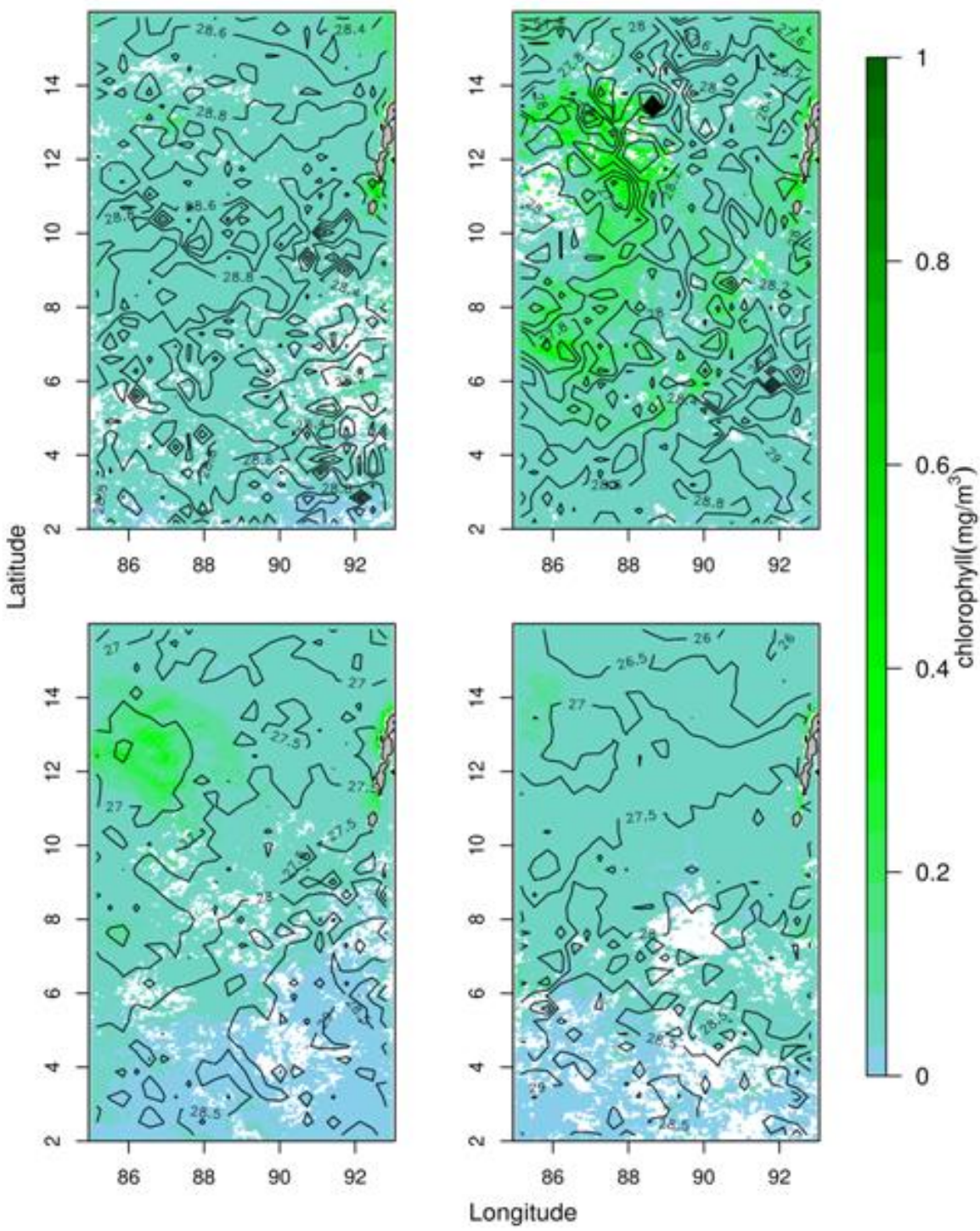

Fig.8 Overlap map of SST and Chl a during a) November, b) December, c) January, d) February 
Ocean Sci. Discuss., https://doi.org/10.5194/os-2018-23

Manuscript under review for journal Ocean Sci.

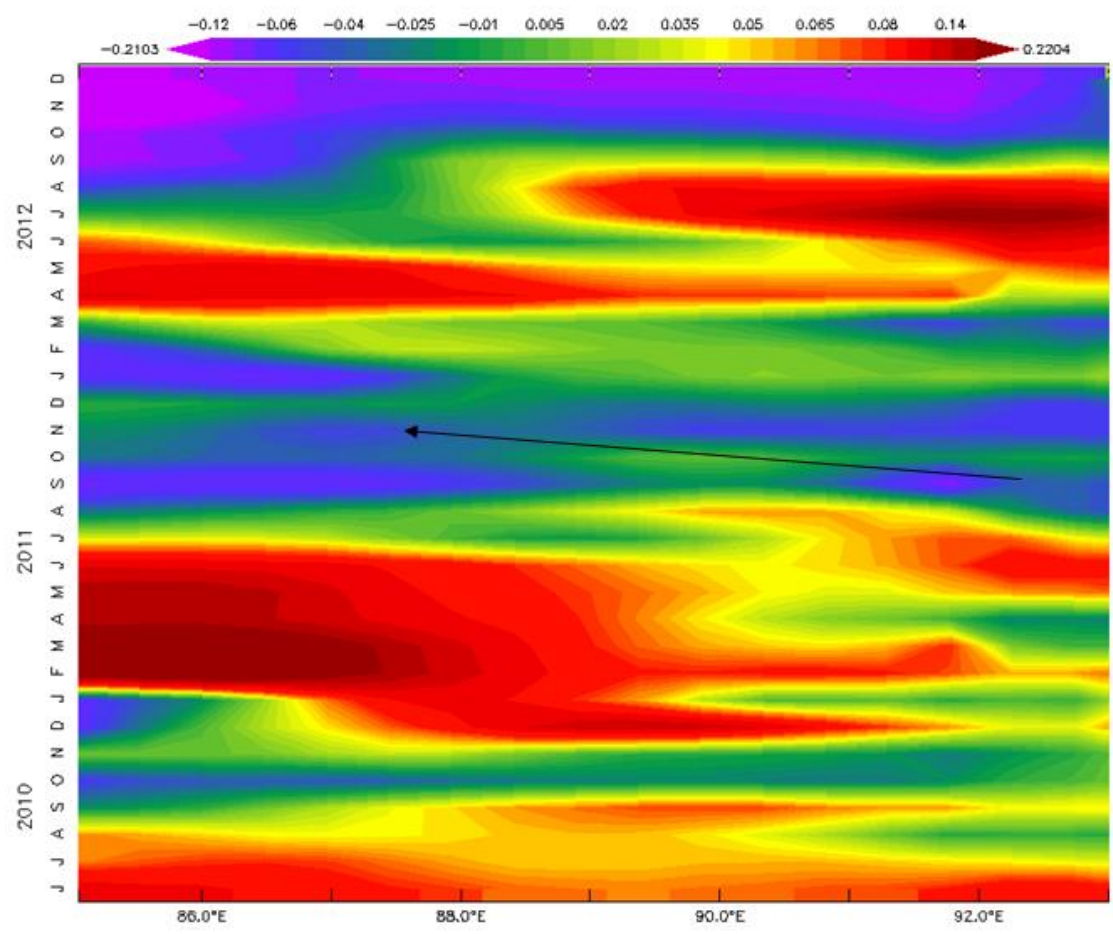

Fig. 9 Hovmuller of SSHA along $13^{\circ} \mathrm{N}$

Table. 1 . Distribution of $\mathrm{DO}, \mathrm{NO}_{3}, \mathrm{PO}_{4} \& \mathrm{SiO}_{4}$ in the eddy region

\begin{tabular}{|c|c|c|c|c|c|c|c|}
\hline Lat. $\left({ }^{\circ} \mathbf{N}\right)$ & Long. $\left({ }^{\circ} \mathbf{E}\right)$ & $\begin{array}{c}\text { Depth } \\
(\mathbf{M})\end{array}$ & Depths & $\begin{array}{c}\mathbf{N O}_{3} \\
\boldsymbol{\mu M}\end{array}$ & $\begin{array}{c}\mathbf{S I O}_{4} \\
\boldsymbol{\mu M}\end{array}$ & $\begin{array}{c}\mathbf{P O}_{4} \\
\boldsymbol{\mu M}\end{array}$ & $\begin{array}{c}\mathbf{D O} \\
(\mathbf{m l} / \mathbf{L})\end{array}$ \\
\hline 8.00 & 92.33 & 1132 & 0 & 0.67 & 0.77 & 0.12 & 4.38 \\
\hline & & & 10 & 0.31 & 0.52 & 0.09 & 4.69 \\
\hline & & & 20 & 0.22 & 0.36 & 0.06 & 4.41 \\
\hline & & & 30 & 0.16 & 0.19 & 0.09 & 4.56 \\
\hline & & & 50 & 0.14 & 0.10 & 0.11 & 4.33 \\
\hline & & & 75 & 9.05 & 13.59 & 0.66 & 1.85 \\
\hline & & & 100 & 18.26 & 21.05 & 1.02 & 1.09 \\
\hline & & & 120 & 20.01 & 21.98 & 1.10 & 2.03 \\
\hline & & & 150 & 24.62 & 15.48 & 0.88 & 0.64 \\
\hline & & & 200 & 27.66 & 25.17 & 1.29 & 0.51 \\
\hline & & & 300 & 31.96 & 35.47 & 1.54 & 0.27 \\
\hline
\end{tabular}


Ocean Sci. Discuss., https://doi.org/10.5194/os-2018-23

Manuscript under review for journal Ocean Sci.

Discussion started: 14 June 2018

\begin{tabular}{|c|c|c|c|c|c|c|c|}
\hline & & & 500 & 37.46 & 44.01 & 1.58 & 0.23 \\
\hline & & & 750 & 38.72 & 67.99 & 1.75 & 0.71 \\
\hline & & & 1000 & 31.83 & 78.11 & 1.74 & 1.00 \\
\hline \multirow{14}{*}{8.00} & 92.89 & 1052 & 0 & 0.59 & 0.18 & 0.11 & 4.79 \\
\hline & & & 10 & 0.14 & 0.13 & 0.09 & 4.60 \\
\hline & & & 20 & 0.62 & 0.69 & 0.09 & 4.93 \\
\hline & & & 30 & 1.32 & 1.72 & 0.13 & 4.56 \\
\hline & & & 50 & 4.14 & 6.43 & 0.30 & 2.96 \\
\hline & & & 75 & 10.02 & 16.54 & 0.68 & 2.02 \\
\hline & & & 100 & 14.00 & 18.17 & 0.84 & 1.57 \\
\hline & & & 120 & 19.12 & 24.94 & 1.12 & 0.91 \\
\hline & & & 150 & 22.02 & 25.82 & 1.20 & 0.81 \\
\hline & & & 200 & 25.07 & 31.29 & 1.36 & 0.60 \\
\hline & & & 300 & 29.18 & 35.62 & 1.50 & 0.36 \\
\hline & & & 500 & 32.10 & 45.72 & 1.60 & 0.40 \\
\hline & & & 750 & 34.20 & 64.89 & 1.79 & 0.75 \\
\hline & & & 1000 & 37.22 & 81.82 & 1.80 & 1.25 \\
\hline \multirow[t]{10}{*}{8.00} & 93.25 & 215 & 0 & 0.98 & 0.44 & 0.15 & 4.73 \\
\hline & & & 10 & 0.21 & 1.90 & 0.14 & 5.00 \\
\hline & & & 20 & 0.24 & 1.94 & 0.16 & 4.71 \\
\hline & & & 30 & 2.03 & 6.69 & 0.30 & 3.85 \\
\hline & & & 50 & 8.01 & 13.89 & 0.63 & 2.49 \\
\hline & & & 75 & 10.02 & 18.88 & 0.88 & 1.70 \\
\hline & & & 100 & 17.04 & 25.36 & 1.07 & 1.42 \\
\hline & & & 120 & 24.09 & 27.26 & 1.20 & 1.37 \\
\hline & & & 150 & 28.35 & 31.88 & 1.38 & 0.79 \\
\hline & & & 200 & 31.01 & 36.47 & 1.47 & 0.63 \\
\hline \multirow[t]{7}{*}{8.00} & 93.28 & 100 & 0 & 0.83 & 0.64 & 0.18 & 4.63 \\
\hline & & & 10 & 0.07 & 0.48 & 0.15 & 5.37 \\
\hline & & & 20 & 1.08 & 1.20 & 0.18 & 4.49 \\
\hline & & & 30 & 1.78 & 2.89 & 0.23 & 4.46 \\
\hline & & & 50 & 4.65 & 5.69 & 0.30 & 4.00 \\
\hline & & & 75 & 15.38 & 17.09 & 0.66 & 2.25 \\
\hline & & & 100 & 23.50 & 20.87 & 0.96 & 1.49 \\
\hline \multirow[t]{5}{*}{8.00} & 93.29 & 68 & 0 & 0.71 & 1.62 & 0.27 & 4.71 \\
\hline & & & 10 & 2.14 & 6.50 & 0.39 & 4.85 \\
\hline & & & 20 & 2.31 & 7.14 & 0.35 & 4.57 \\
\hline & & & 30 & 3.19 & 7.86 & 0.39 & 4.48 \\
\hline & & & 50 & 5.05 & 8.64 & 0.45 & 3.59 \\
\hline
\end{tabular}

